


\title{
Vertical profile of polycyclic aromatic hydrocarbons in the core sediment found in Langkawi, Kedah
}

\author{
R.C. Terence and M.A. Masni*
}

Department of Earth Sciences and Environment, Faculty of Science and Technology, Universiti Kebangsaan Malaysia, Bangi, 43600, Malaysia.

*Corresponding Author Email : masni@ukm.edu.my

\section{Abstract}

Aim: To determine the concentration of PAHs by layers in each core sediment around one of Malaysia's tourism-oriented areas and to distinguish and classify the origin of PAHs in core sediments using index of molecular ratios.

Methodology: The individual compounds and sources of polycyclic aromatic hydrocarbon (PAHs) were studied in $72 \mathrm{~cm}$ and $54 \mathrm{~cm}$ long sediment core, each that were taken in the Kuah Jetty and a rural area between Tanjung Ayer and Tanjung Batu Kulat of Langkawi Island. A total of 12 PAHs were determined and quantified by gas chromatography coupled with mass spectrometry (GC-MS).

Results: Kuah Jetty, Langkawi's total PAH concentrations of sediment core layers ranged from $45.82 \mathrm{ng} \mathrm{g}-1$ to $252.43 \mathrm{ng}$ g-1. Furthermore, the total PAH concentrations of the sediment core layers from the rural area between Tanjung Ayer and Tanjung Batu Kulat ranged between $28.97 \mathrm{ng} \mathrm{g}^{-1}$ to $312.20 \mathrm{ng} \mathrm{g}^{-1}$.

Interpretation: The potential application of a combination of molecular ratios and individual concentrations of $\mathrm{PAH}$ in determining the origin and source of pollution in sediments resulted in the determination of low to moderate pollution and indicated mixed sources of PAHs in the study area.

Key words: Core sediments, GC-MS, Molecular ratio index, Polycyclic aromatic hydrocarbons, Petrogenic
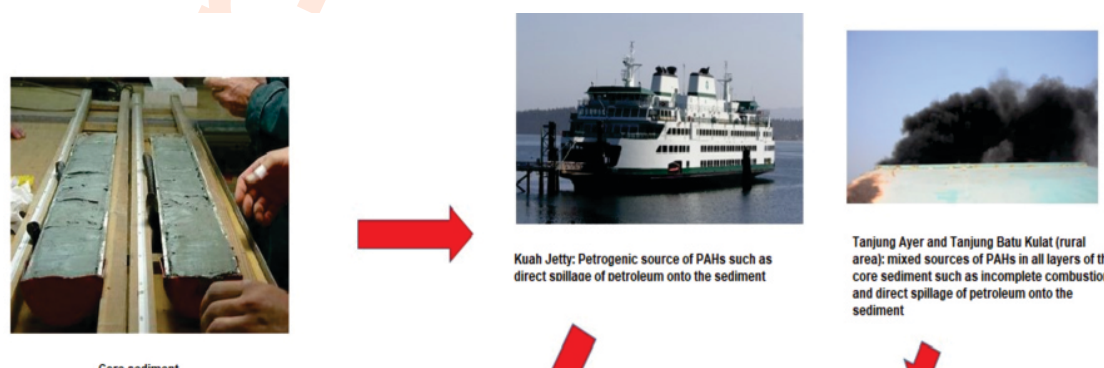

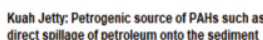

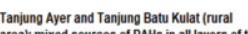
Tanjung Ayer and Tanjung Batu kulat (rural
areak mixed sources of PAHs in all layers of the core sediment such as incomplete combus ediment






\section{Introduction}

Polycyclic Aromatic Hydrocarbon (PAHs) are harmful and carcinogenic compound present in the environment (Tsang et al., 2011; Christensen and Arora, 1998). It is also environmentally ubiquitous and cause adverse effects on the environment (Olayinka et al., 2019). Furthermore, it also serves as pervasive pollutants which have carcinogenic and mutagenic properties (Wilson and Joins, 1993; Menzie and Potokib, 1992). In addition to natural sources, PAHs are often produced during incomplete combustion, pyrosynthesis, or hydrocarbon pyrolysis (petrogenesis) and released from anthropogenic sources into the environment (Boonyatumanond et al., 2006; Lowe and Silverman, 1984). The main sources of PAHs are from exploration and development of crude oil and gas resources. Despite the introduction of improved technologies in the petroleum industry, accidents continue to occur, leading to pollution environmental by hydrocarbons (both land and water) in most oil producing countries (Farrington, 2014). Incomplete combustion of fossil fuels, biomass, and municipal waste are the main contributors to PAHs in the environment (Yunker et al., 2002), petroleum-based products, and the organic matters that are being diagenesis in the oxygen-deprived environment (Berrojalbiz et al., 2011; Lima et al., 2005). Based on their physical and biological properties, low and high molecular weights, and the number of fused aromatic rings found in their structure, polycyclic aromatic hydrocarbons are divided into two main groups. Low or small molecular weight PAHs consists 2-3 aromatic rings and 4-6 heavy or large molecular (HMW) PAH rings (Abou-Arab et al., 2014; Lee, 2010). The chemical structure, chemical configuration and physical and chemical properties of aromatic rings influence the stability and distribution of PAHs in the natural environment (Ahmed et al., 2016; Lee, 2010). Most studies on PAHs were conducted conducted on surface sediment samples around the world, and the core sediment was studied to gain a better understanding because deposition of pollutant is different at different times, leading to variations in the PAHs at different depths. The differences in the energy structure and economic growth are due to these differences (Guo et al., 2010; Guo et al., 2007).

As in our case zone, the jetty of Langkawi is one of the highly used as a hub of tourism-based transportation regions in the world and one of the most well-known tourist destinations in Malaysia. A significant amount of input entering the area has resulted from the growing tourism activities in the jetty area. Overall, Langkawi covers $478.48 \mathrm{~km}^{2}$ (including the adjacent islands). Just three of these islands, mainly Langkawi, Tuba, and Dayang Bunting Island are inhabited. Langkawi Island is dominated by forest-rich mountains, indigenous trees, and valleys, and surrounded by limestone buildings. It is about $30 \mathrm{~km}$ from Kuala Perlis, $109 \mathrm{~km}$ from Penang and $51.5 \mathrm{~km}$ from Kuala Kedah, respectively. Langkawi's man-made tourism products and stunning natural beauty make this island a well-known tourist destination, especially after the Malaysian government announced it as a duty-free island in 1987. Economic development in Langkawi had further intensified with the establishment of the Langkawi Development Board (LADA) in 1990 (LADA, 2017). LADA is responsible for executing and preparing the growth of Langkawi. Both public and private organisations, however, are strongly engaged in tourism-related initiatives and projects to boost the growth of tourism on this island, thereby adding to Yussof and Omar (2007) overall national growth (LADA, 2017). Until Langkawi became a popular tourist destination, the main source of income for the local population was fishing and agricultural activities. The rest were either conventional fishermen from offshore or small-scale farmers. However, tourism developments in this island had gradually transformed the economic activities of local community. Business and service sectors which are mostly tourism-based provide new economic opportunities for the local community to garner income (Norlida et al., 2014).

This current research is to determine the concentration of PAHs by layers in each core sediment around one of the tourismoriented areas in Malaysia, and it will also contain valuable information investigating historical trends of PAHs in the sediment core. This study also aims to differentiate and identify the sources of PAHs in the core sediments by molecular ratio index.

\section{Materials and Methods}

Study area : Langkawi island is located in the northwest of Peninsular Malaysia in the state of Kedah, Malaysia. Two sediment core samples were taken at $\mathrm{N} \mathrm{6} 6^{\circ} 18^{\prime 2} 27.81^{\prime \prime}$ and $\mathrm{E}$ $99^{\circ} 50^{\prime} 39.31$ " on 3 March 2013 at a depth of $5.1 \mathrm{~m}$ (Station 1) and another was taken at N 6²7'31.16" and E 99 $49^{\prime} 22.97^{\prime \prime}$ at a depth of $8.8 \mathrm{~m}$ (Station 2). These sampling stations were selected due to their location. Station 1 was located adjacent to the jetty where a significant number of activities occur. The other sampling station was located in the rural area of Tanjung Ayer and Tanjung Batu Kulat in the northern side of the Langkawi island where the activities are comparatively limited. In order to collect the core sediment samples, a gravity sediment core grab was used to penetrate the seabed, and the sample was taken back on the sampling boat to be sliced from the long cylindrical shape samples into $3 \mathrm{~cm}$ sub-samples. There was a total of $72 \mathrm{~cm}$ long core sediment taken at the Kuah Jetty while $54 \mathrm{~cm}$ long core sediment was taken from the rural area of Tanjung Ayer and Tanjung Batu Kulat. All the samples were then preserved in precleaned glass jars. All the samples were frozen at $4^{\circ} \mathrm{C}$ prior to analysis.

Laboratory analysis: In order to eliminate any water content, a total of $20 \mathrm{~g}$ of sediment sample from each station was taken and mixed with sodium anhydrous. The dried sample was placed in a thimble extractor ( $30 \mathrm{~mm} \times 150 \mathrm{~mm}$ ) and extracted for about $10 \mathrm{hr}$ with dichloromethane. Approximately, $250 \mathrm{ml}$ of dichloromethane was then placed on a heater in a round bottom flask and heated to 
$60^{\circ} \mathrm{C}$. The extract was evaporated to near dryness after $10 \mathrm{hr}$ using a rotary evaporator. Later, the residue was diluted with dichloromethane and transferred in to a vial. Total extractable lipid was termed from the residue. Total extractable lipid extracts were split into two phases of column chromatography of the silica gel. The concentrated sample was then moved to silica gel column and washed with hexane/dichloromethane $(0.4 \mathrm{ml}, 0.3 \mathrm{ml}, 0.3 \mathrm{ml}$, $0.5 \mathrm{ml}$ and $0.5 \mathrm{ml}$ ) and then with $18 \mathrm{ml}$ of hexane/ dichloromethane. The hydrocarbons were then extracted into a conical flask ranging from n-alkanes to PAHs. The rotary evaporator concentrated eluent was developed from the first phase chromatography, and PAH fraction was collected with hexane/dichloromethane mixture. The fraction of PAH was labelled and stored in the freezer until further analysis. PAH samples were then transferred to vial and injected to determine the concentration of PAH compounds. Prior injecting into the GCMS (GC, 6890N coupled with 5975C MSD, Agilent, USA), it underwent nitrogen blowdown evaporation process and was refilled with distilled $n$-hexane. Helium as a carrier gas was fixed @ $1 \mathrm{ml} \mathrm{min}{ }^{-1}$ at $158 \mathrm{kpa}$. A HP-5 fused silica capillary column was used to isolate the compounds at $270^{\circ} \mathrm{C}$ in split-less mode. The temperature gradient of $\mathrm{GC}$ was $40^{\circ} \mathrm{C}$, which increased to $8^{\circ} \mathrm{C}$ $\min ^{-1}$ to $150^{\circ} \mathrm{C}$ and decreased to $5^{\circ} \mathrm{C} \min ^{-1}$ to $310^{\circ} \mathrm{C}$ and then kept for $10 \mathrm{~min}$. The operating conditions of GC-MS were $70 \mathrm{eV}$ ionisation potential with MS source for 1.4 scans per sec at $230^{\circ} \mathrm{C}$, electron multiplier at $1400 \mathrm{~V}$ and dwell time set at $40 \mathrm{sec}$. The temperature of the interface was $280^{\circ} \mathrm{C}$, while the temperature of the injector was maintained at $250^{\circ} \mathrm{C}$. Using MS library to identify the peaks, 12 samples of PAHs were quantified by the ion $\mathrm{m} / \mathrm{z}$ ratio of native standard PAHs (Zakaria et al., 2001).

Quality control and assurance: During analysis, the eradication of any cross-contamination involving simultaneous processing of blank and environmental samples was achieved by inserting the blank sample into each 20 environmental samples. In this study, the optimum efficiency was carefully preserved during the injection of GC-MS. The validation of PAH peaks was calculated by MS library crossing and abundance of quantification ions of individual PAHs with 12 PAHs mixture, combined with the surrogate standard (phenanthrene and chrysene). In addition, five external standard calibration curve points (L20950018AL, Dr. Ehrenstorfer $\mathrm{GmbH}$, Germany) were developed with a correlation coefficient of more than 0.990 , in the range of $0.1-1.0 \mathrm{ppm}$. The Process Detection Limit was also obtained to ensure the detection limits for each PAHs (Zakaria et al., 2001).

\section{Results and Discussion}

Composition of PAHs: Measuring and identifying the vertical distribution of the PAHs in sediment core is an effective method to explore the historical trend of PAHs in the sediment (Xu et al., 2014). For areas close to tourism ports as comparisons for this study with the previous studies, Olbia harbour (a tourist harbour located in northern Sardinia, Italy) (Luca et al., 2005),



Fig. 1 : Station 1 PAHs concentration vertical profile.

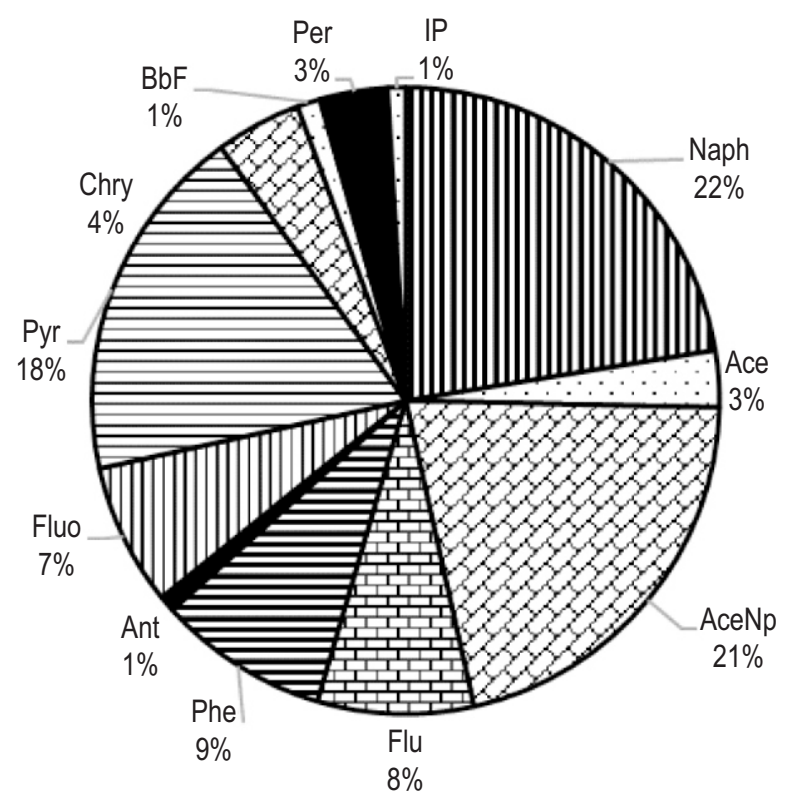

Fig. 2 : Station 1 PAHs compounds concentration percentage. 


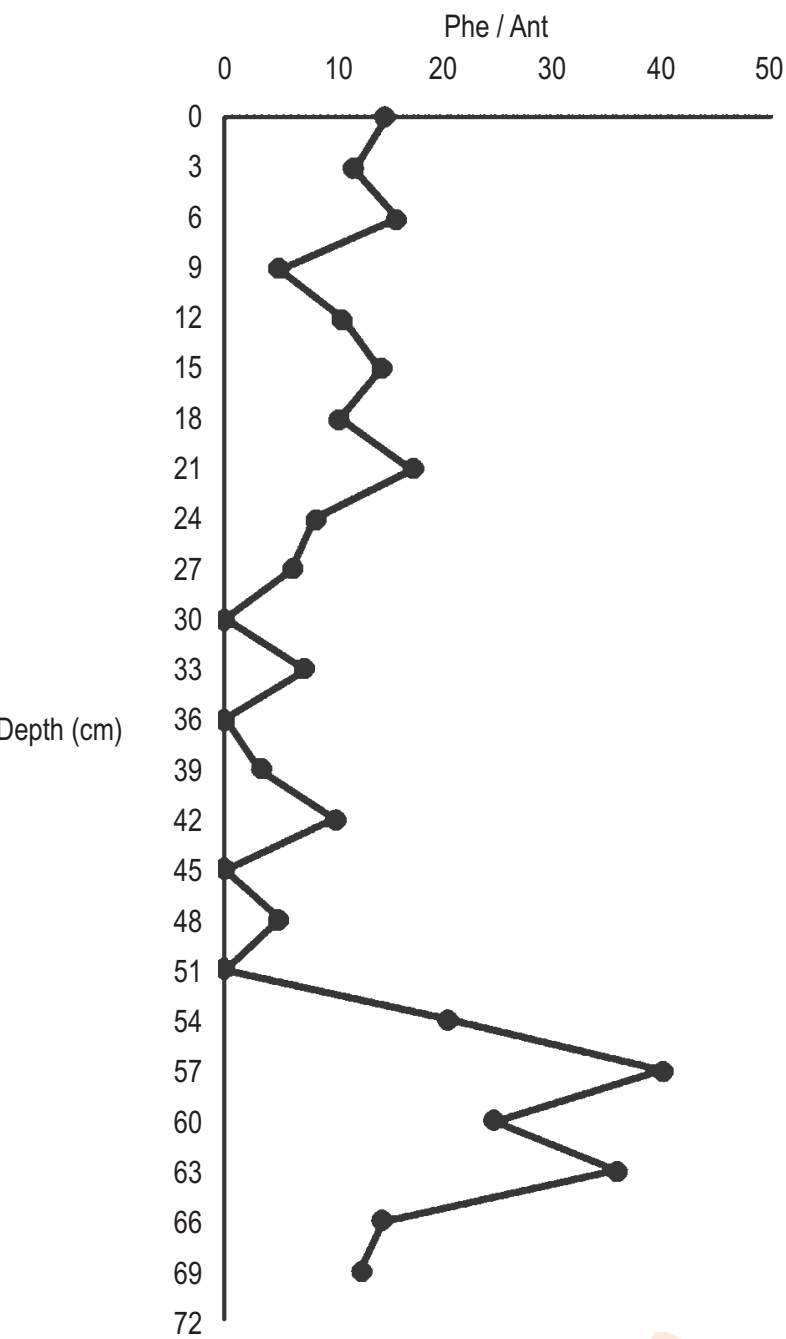

Fig. 3 : Station 1 Phe/Ant molecular ratio.

Merambong Island, Johor, Malaysia (Vaezzadeh et al., 2014), Kenting National Park, Taiwan (Ko et al., 2014) are the closest matches for the areas that resembles similar conditions with the current study in Langkawi island.

Based on Fig. 1, the core samples from Station 1 indicated that the highest concentration $\left(252.43 \mathrm{ng} \mathrm{g}^{-1}\right)$ of PAHs was detected at $18-21 \mathrm{~cm}$ depth. These high concentrations of PAHs can be attributed to industrial activities such as tourism and household wastes that are deposited on the site and to the intermittent open burning of them (Riaz et al., 2019). The lowest concentration (45.82 $\left.\mathrm{ng} \mathrm{g}^{-1}\right)$ of PAHs was detected at $48-51 \mathrm{~cm}$ depth. The total concentrations of PAHs declined further as the core sediment went deeper. The upper layer of the core sediment layers $(0-18 \mathrm{~cm})$ has an average total of concentration between 150-200 $\mathrm{ng} \mathrm{g}^{-1}$ total PAHs. A significant decrease of the total concentration can be observed at the $18-21 \mathrm{~cm}$ layer. The trend decreased gradually and become almost stagnant with less than



Fig. 4 : Station 1 Fluo/Pyr molecular ratio.

$100 \mathrm{ng} \mathrm{g}^{-1}$ total PAHs concentration. With reference to Fig. 2, the highest concentration of PAHs compound is naphthalene with a total concentration of $568.68 \mathrm{ng} \mathrm{g}^{-1}(22 \%)$. The primary sources of naphthalene are oil refineries, petrol stations, heavy traffic areas and vehicle exhaust systems (Phale et al., 2019). It was observed that several ferries docked in the jetty area throughout the day and being the transit point of ferries going in and out of Langkawi. The lowest concentration of PAHs compound is anthracene with $1 \%$ of the total concentration $\left(21.14 \mathrm{ng} \mathrm{g}^{-1}\right)$. Naturally, anthracene is a part of fossil fuels (coal tar, oil and gas) and is produced during incomplete combustion and processing of coal, oil, gas and materials from plants such as wood (Adrian and Wayne, 2012). Apart from that, it was also observed that the second major compound of PAHs detected is acenaphthene with a total concentration of $536.48 \mathrm{ng} \mathrm{g}^{-1}(21 \%)$. Acenaphthene is an ingredient of crude oil and a product of combustion that can be generated during natural fires and released into the atmosphere. Emissions from the production of gasoline, coal tar distillation, 
coal burning, and diesel engines are the major sources of acenaphthene in the atmosphere (Chanda and Mehendale, 2005).

For the core samples from Station 2, as seen in Fig. 5, the highest concentration of PAHs detected is in the depth of between $33-36 \mathrm{~cm}$ with a total of $312.20 \mathrm{ng} \mathrm{g}^{-1}$. Another factor that may have promoted more PAHs in sediment is reduced water movement, which allows resident time for the accumulation of PAHs in the surface sediments (Wu et al., 2019). The lowest concentration of PAHs detected is in the depth of between 48-51 $\mathrm{cm}$ with a total of $28.97 \mathrm{ng} \mathrm{g}^{-1}$. The results indicate a decrease in the concentration of PAHs at $0-3 \mathrm{~cm}$ depth, but it gradually increased $3 \mathrm{~cm}$ to $15 \mathrm{~cm}$. Subsequently, a mixed pattern was observed between the layers of $15-21 \mathrm{~cm}$ whereas the value of concentration varied from as low as $58.5 \mathrm{ng} \mathrm{g}^{-1}$ to as high as $312.19 \mathrm{ng} \mathrm{g}^{-1}$. In Fig. 6, the highest concentration of the PAHs compound is pyrene with $44 \%$ of the total PAHs (1045.4 $\left.\mathrm{ng} \mathrm{g}^{-1}\right)$. Pyrene forms during incomplete combustion of fossil fuels (Chanda and Mehendale, 2005). The lowest concentration of PAHs compound is fluorene with an overall total of $1 \%$ with 21.45 $\mathrm{ng} \mathrm{g}^{-1}$. The primary source of fluorene is coal tar (Burns and lball, 1954). Apart from that, the second major PAHs compound detected with $16 \%$ of the total concentration is naphthalene $\left(387.41 \mathrm{ng} \mathrm{g}^{-1}\right)$. The value of naphthalene in station 2 was lower than station 1 which valued $568.68 \mathrm{ng} \mathrm{g}^{-1}$. As we can see the value of naphthalene in station 2 is lower than station 1 which valued $568.68 \mathrm{ng} \mathrm{g}^{-1}$. This is due to the remote location of station 2 compared to the activities centralized station 1. The amount of organic matter discharged into the environment, the presence of industries such as tourism, the discharge of wastes and effluents, the rate of evaporation and volatility, photo-oxidation processes, bacteria responsible for biodegradation, and the temperature of the environment are all factors that influence the concentration of PAHs in sediment or water. (Edori et al., 2020). For areas close to tourism ports as comparisons for this study with the previous studies, total PAH concentration in the sediments collected from Olbia harbour (a tourist harbour located in northern Sardinia, Italy) ranged from 160 to $770 \mathrm{ng} \mathrm{g}^{-1}$ (Luca et al., 2005), 38.6 to $122.8 \mathrm{ng} \mathrm{g}^{-1}$ from Merambong Island, Johor, Malaysia (Vaezzadeh et al., 2014), and 2 to $59 \mathrm{ng} \mathrm{g}^{-1}$ in the ambient sediment of Kenting National Park, Taiwan (Ko et al., 2014). Baumard et al. (1998) reported that $0-1000 \mathrm{ng} \mathrm{g}^{-1} \mathrm{PAHs}$ in sediment is considered as low to moderate pollution.

Molecular ratio index: For the core sediment samples taken from Station 1, there are 5 layers showing values of $<10$ for the Phe/Ant molecular ratio, which are layer $9-12 \mathrm{~cm}, 27-30 \mathrm{~cm}, 33-$ $36 \mathrm{~cm}, 39-42 \mathrm{~cm}$ and $48-51 \mathrm{~cm}$ (Fig. 3). A molecular index that shows less than 10 for Phe/Ant ratio indicates pyrolytic source. This is due to the factors formed mainly by sporadic change in temperature or partial burning of organic carbon, such as petroleum, fossil fuels and coal (Yendry et al., 2020; Abdel-Shafy

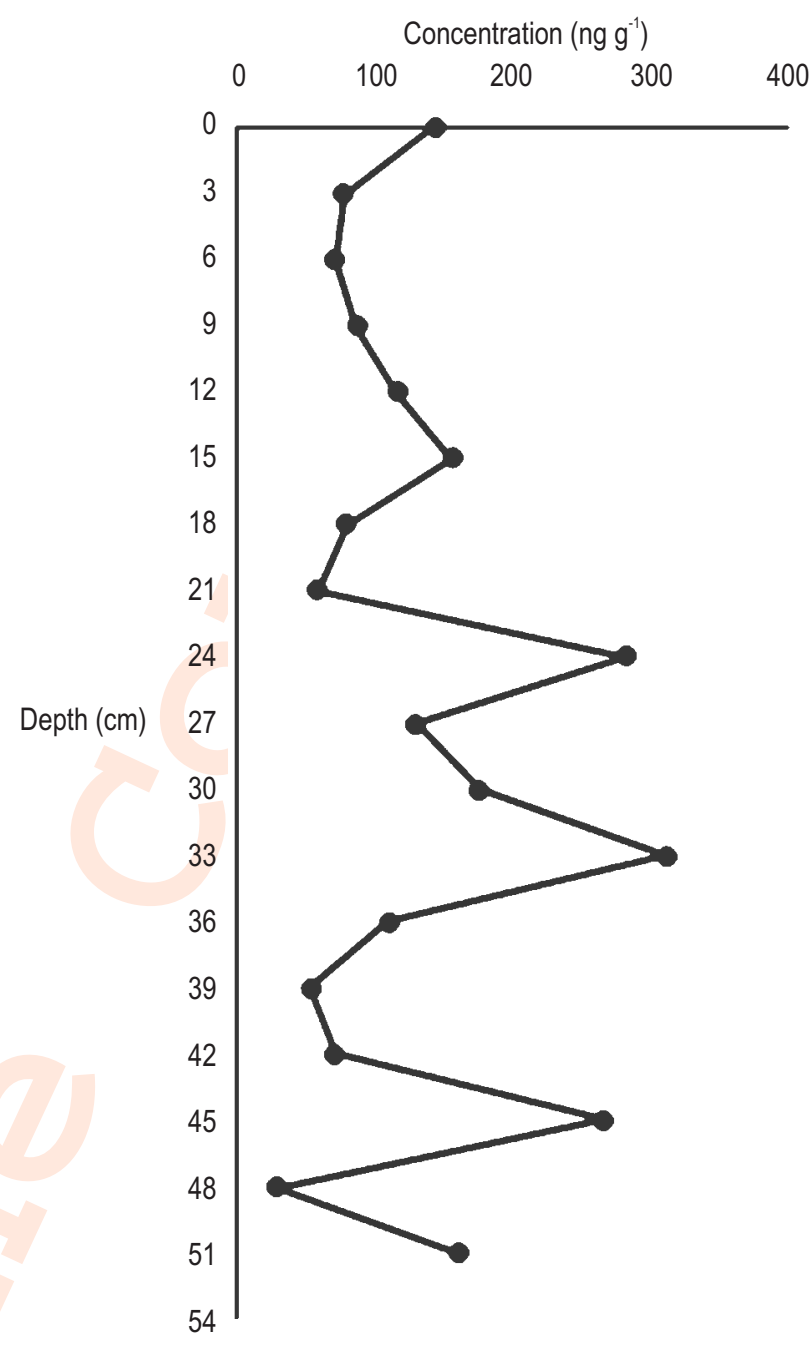

Fig. 5 : Station 2 PAHs concentration vertical profile.

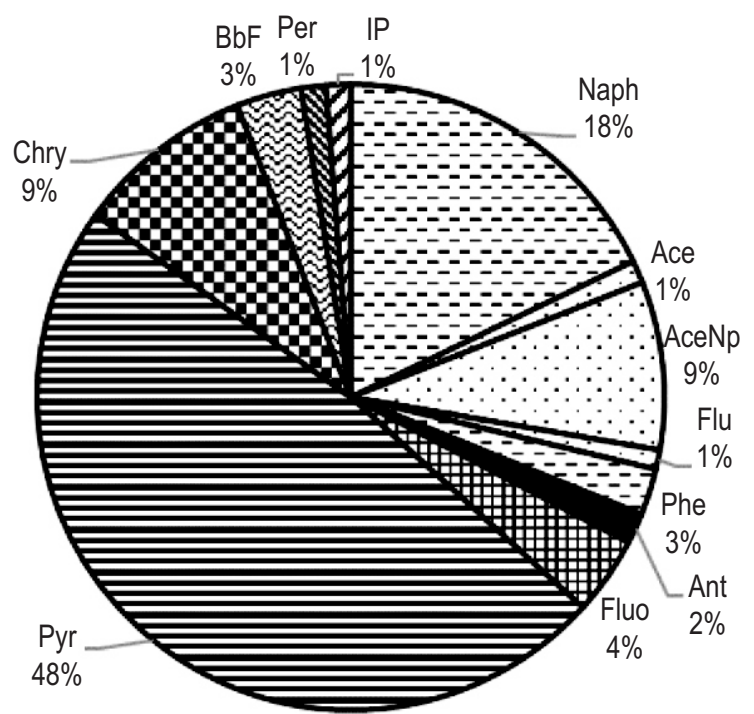

Fig. 6 : Station 2 PAH compounds percentage. 


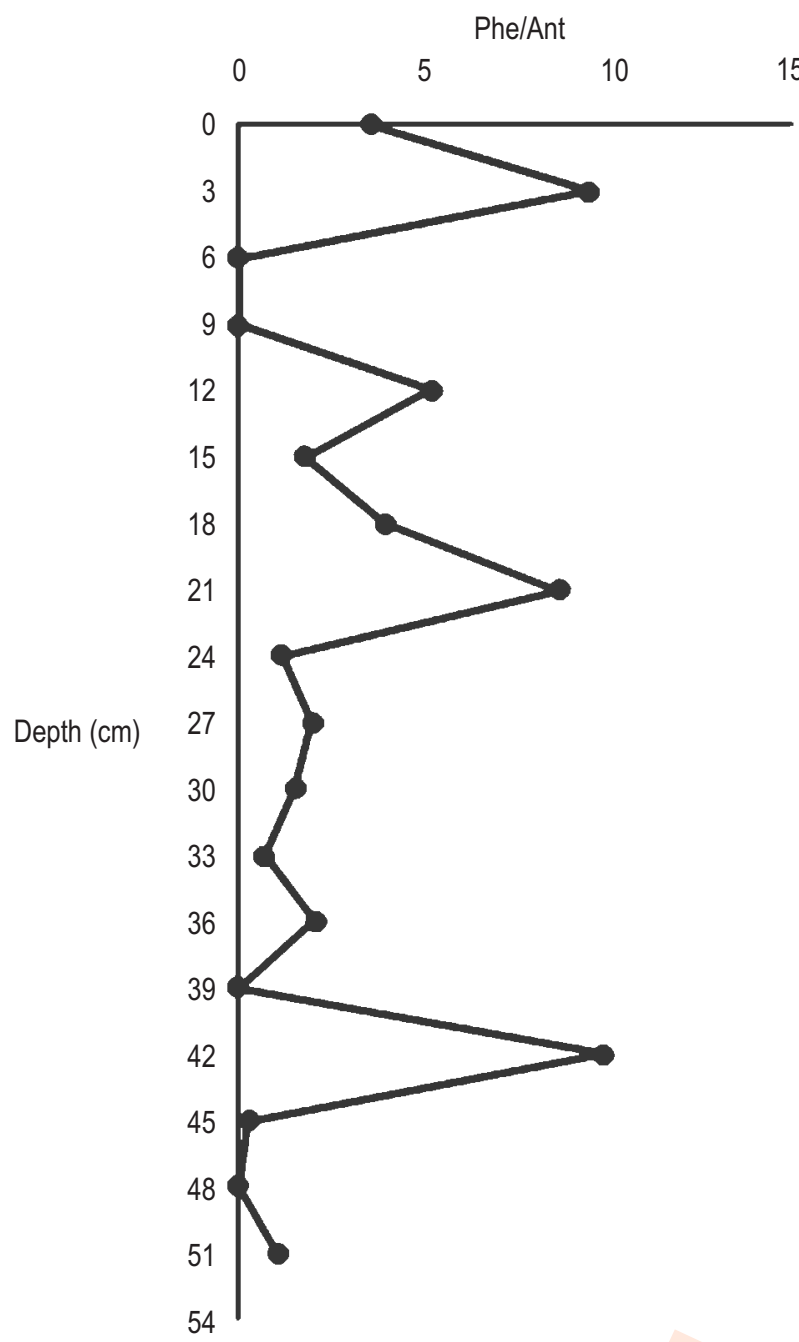

Fig. 7 : Station 2 Phe/Ant molecular ratio.

and Mansour, 2016). The main town island lies close to Kuah Jetty where most activities are concentrated and commercial and district offices located. The number of vehicles are also increasing each year in the island that most possibly contribute to gas emission. They enter sediments through particular matter deposition (Shi et al., 2012). They most probably enter the sediment when PAHs interact with atmospheric particulate material (Zhao et al., 2019), as a result, PAHs are transported by air and then deposited in soils and sediments which serve as sinks for pollutants. Apart from that, a value of value more than 10 in the petrogenic source indicates that this core sediment is dominated by petrogenic source of PAHs. Petrogenic resources are most likely contributed by commercial ferries that use Kuah Jetty on a daily basis, and this is intensified by the increasing number of tourists visiting the island. Fluoranthene to pyrene ratios are most widely used for determining the sources of PAHs (Zhu et al., 2008; Budzinski et al., 1997), because the concentration of pyrene in the fossil fuel and their by-products

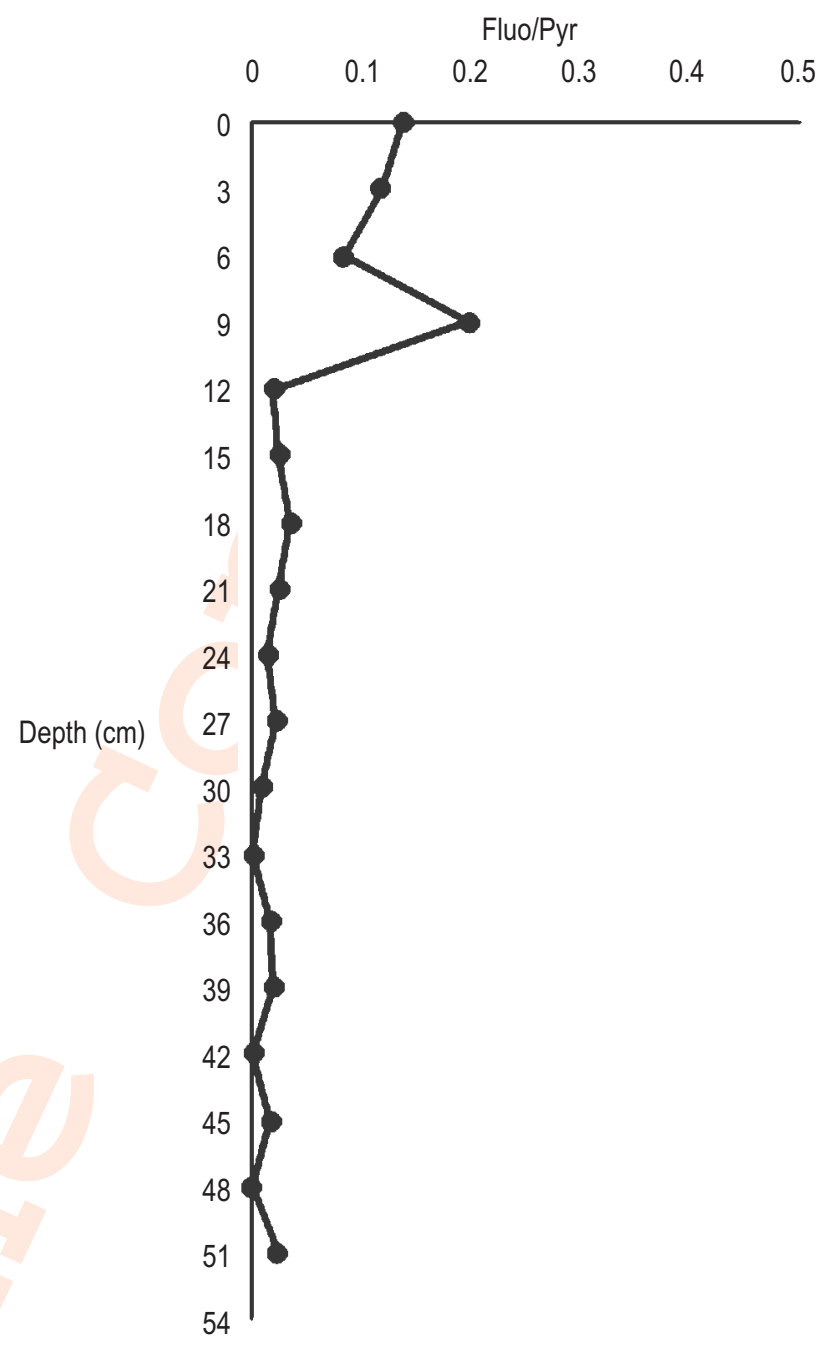

Fig. 8 : Station 2 Fluo/Pyr molecular ratio.

are higher than fluoranthene concentration (Sanders et al., 2002). As far as Fluo/Pyr molecular ratio is concerned from Fig. 4 , all the layers indicated a value less than 1 , indicating that all the layers were based in the petrogenic source of PAHs (Baumard et al., 1998). Fig. 7, 8 reveals that the sediment samples collected from Station 2, the Phe/Ant molecular ratio was less than 10 which indicated the pyrolytic source As for the Fluo/Pyr molecular ratio. As for the Fluo/Pyr molecular ratio, all the values were less than 1 which indicated the petrogenic source (Baumard et al.,1998). Thus, it can be deduced that the core sediment sample from Station 2 implies mixed PAHs sources. As the core is from Station 2 which is far away to the north side of the island, there are less commercial ferries or other types of boat that pass by. Thus, they do not contribute much to the direct spillage of petroleum to the sediment. The remoteness of the location of sampling stations may result in less land vehicle emissions to the surrounding area causing PAHs in the area to have mixed sources. 
This study provides information of sediment PAHs in the core sample of Langkawi, thus helping to fill the knowledge gap of this complex area and providing useful information for environmental management. The PAH concentration found in this study show that Kuah Jetty of the Langkawi Island is not heavily polluted. The molecular index values imply that petrogenic processes to be the most probable source of PAHs contamination in the study area. Station 2 located near Tanjung Ayer and Tanjung Batu Kulat rural area, the molecular ratio indicated a mixed source of PAHs. The basic and molecular index ratio analyses used in this study provides a clear understanding of the composition of organic matter and their sources. Last but not least, increased patronage of public transport and transition from internal combustion engines to more environmentally friendly alternatives such as solar and hybrid vehicles would help to minimise the load of vehicular emission of PAHs. These recommendations can help to curb $\mathrm{PAH}$ pollution in other parts of the world too.

\section{Acknowledgments}

The authors would like to thank the Malaysian Ministry of Science, Technology and Innovation (MOSTI) and the E-Science Fund of Universiti Kebangsaan Malaysia 04-01-02-SF0698.

\section{Add-on Information}

Authors' contribution : R.C. Terence: did the experiment, conceived of the presented idea, wrote the first draft, M.A. Masni: Supervised, contributed to final version.

Research content : The research content of manuscript is original and has not been published elsewhere.

\section{Ethical approval : NotApplicable}

Conflict of interest : The authors declare that there is no conflict of interest.

\section{Data from other sources : NotApplicable}

Consent to publish : All authors agree to publish the paper in Journal of Environmental Biology.

\section{References}

Abou-Arab, A.A., M.A. Abou-Donia, F.M. El-Dars, O.I. Ali and A.G. Hossam: Detection of polycyclic aromatic hydrocarbons levels in Egyptian meat and milk after heat treatment by gas chromatography-mass spectrometry. Int. J. Curr. Microbiol. Appl. Sci., 3, 294-305 (2014).

Abdel-Shafy, H.I and M.S.M. Mansour: A review on polycyclic aromatic hydrocarbons: Source, environmental impact, effect on human health and remediation. Egypt. J. Pet., 25, 107-123 (2016).

Adrian, G. and F.K. Wayne: Assessing anthracene and arsenic contamination within Buffalo River sediments. Int. J. Eco., 2012, 78-97 (2012)
Ahmed, M.T., F. Malhat and N. Loutfy: Residue levels, profiles, emission source and daily intake of polycyclic aromatic hydrocarbons based on smoked fish consumption, an Egyptian pilot study. Polycycl. Aromat. Compd., 36, 183-96 (2016).

Baumard, P., H. Budzinski and P. Garrigues: PAHs in Arcachon Bay, France: Origin and biomonitoring with caged organisms. Mar. Pollut. Bull., 36, 577-586 (1998).

Berrojalbiz, N., J. Dashes, M.J. Ojeda, M.C. Valle, J. Castro-Jimenez, J. Wollgast, M. Ghiani, G. Hanke and J.M. Zaldivar: Biogeochemical and physical controls on concentrations of polycyclic aromatic hydrocarbons in water and plankton of the Mediteranean and Black seas. Global Biogechem. Cycles, 25, GB4003 (2011).

Boonyatumanond, R., G. Wattayakorn, A. Togo and H. Takad: Distribution and origins of polycyclic aromatic hydrocarbons (PAHs) in riverine, estuarine, and marine sediments in Thailand. Mar. Pollut. Bull., 52, 942-956 (2006).

Budzinski, H., I. Jones, J. Bellocq, C. Piérard and P.H. Garrigues: Evaluation of sediment contamination by polycyclic aromatic hydrocarbons in the Gironde estuary. Mar. Chem., 58, 85-97 (1997).

Burns, D.M. and J. Iball: Molecular structure of fluorene. Nature, 173, 635 (1954).

Chanda, S. and H.M. Mehendale: Acenaphthene. In: Encyclopedia of Toxicology (Ed.: P. Wexler). $2^{\text {nd }}$ Edn., Academic Press, Elsevier, Cambridge, USA, pp. 11-13 (2005).

Christensen, E.R. and S. Arora: Source apportionment of PAHs in sediments using factor analysis by time records: Application to Lake Michigan, USA. Water Res., 41, 168-176 (2007).

Edori, O. S., E.S. Edori and W.A. Iyama: Investigation and assessment of polycyclic aromatic hydrocarbons concentrations in sediments at drainage discharge points into the mangrove stretch of New Calabar River, Port Harcourt, Nigeria. Earth. Env. Sci. Res., 3, 199203 (2020).

Farrington, J.W.: Oil pollution in the marine environment II: Fates and effects of oil spills. Environment: Science \& Policy for Sustainable Development, 56, 16-31 (2014).

Guo, Z., T. Lin, G. Zhang, M. Zheng, Z. Zhang, Y. Hao and M. Fang: The sedimentary fluxes of polycyclic romatic hydrocarbon in the Yangtze river estuary coastal sea for the past century. Sci. Total Environ., 386, 33-41 (2007).

Guo, J.Y., F.C. Wu, X.J. Luo, Z. Liang, H.Q. Liao, R.Y. Zhang, Y.C. Hao and M. Fang: Anthropogenic input of polycyclic aromatic hydrocarbon s into five lakes in Western China. Sci. Total Environ., 386, 33-41 (2010).

Harrison, R.M., D.J.T. Smith and L. Luhana: Source apportionment of atmospheric polycyclic aromatic hydrocarbons collected from an urban location in Birmingham, U.K. Environ. Sci. Technol., 30, 825832 (1996).

LADA: Laporan Tahunan Lembaga Pembangunan Langkawi (Langkawi Development Authority) 2017. LADA, Langkawi, Kedah, Malaysia (2017).

Lima, A.L.C., J.W. Farrington and C.M. Reddy: Combustion-derived polycyclic aromatic hydrocarbons in the environment. A review. Environ. Foren., 6, 109-131 (2005).

Lee, B.K.: Sources, distribution and toxicity of polyaromatic hydrocarbons (PAHs) in particulate matter. In: Air Pollution (Ed.: V. Villanyi). IntechOpen, London, UK, pp. 99-122 (2010).

Lowe, J.P. and B.D. Silverman: Predicting carcinogenicity of polycyclic aromatic hydrocarbons. Acc. Chem. Res., 17, 332-338 (1984). 
Menzie, C.A. and B.B. Potocki: Exposure to carcinogenic PAHs in the environment. Environ. Sci. Technol., 26, 1278-1284 (1992).

Miguel, A.H., T.W. Kirchstetter, R.A. Harley and S.V. Hering: On-road emissions of particulate polycyclic aromatic hydrocarbons and black carbon from gasoline and diesel vehicles. Environ. Sci. Technol., 32, 450-455 (1998).

Norlida, H.M.S., O. Redzuan, H.M.I. Siti, A.H. Sharina, S.S. MD, Y. Ishak, S. Mohd and O. Mustaffa: Development of tourism industry and its impact on Langkawi Island Community. J. Ekon. Malaysia, 48, 7182 (2014).

Olayinka, O.O., A.A. Adewusi and O.O. Olujimi: Polycyclic aromatic hydrocarbons in sediments and helath risk of fish, crab and shrimp around Atlas cove, Nigeria. J. Hlth. Pollut., 9, 191204 (2019).

Phale, P.S., A. Sharma and K. Gautam: Microbial degradation of xenobiotics like aromatic pollutants from the terrestrial environments. In: Pharmaceuticals and Personal Care Products: Waste Management and Treatment Technology (Eds.: M.N.V. Prasad, M. Vithanage and A. Kapley). Butterworth Heinemann Books, Elsevier, Oxford, UK, pp. 259-278 (2019).

Riaz, R., U. Ali, J. Li, G. Zhang, K. Alam, A.J. Sweetman, K.C. Jones and R.N. Malik: Assessing the level and sources of polycyclic aromatic hydrocarbons (PAHs) in soil and sediments along Jhelum riverine system of lesser Himalayan region of Pakistan. Chemosphere, 216, 640-652 (2019).

Sanders, M., S. Sivertsen and G. Scott: Origin and distribution of polycyclic aromatic hydrocarbons in surficial sediments from the Savannah River. Arch. Environ. Contam. Toxicol., 43, 438-448 (2002).

Shi, G.L., Y.Z. Tian, C.S. Guo, Y.C. Feng, J. Xu and Y. Zhang: Sedimentpore water partition of PAH source contributions to the Yellow river using two receptor models. JSS, 12, 1154-1163 (2012).

Tsang, H.L., S. Wu, C.K.M. Leung, S. Tao and M.H. Wong: Body burden of POPs of Hong Kong residents, based on human milk, maternal and cord serum. Environ. Int., 37, 142-151 (2011).

Venkataraman, C., J.M. Lyons and S.K. Friedlander: Size distributions of polycyclic aromatic hydrocarbons and elemental carbon. 1. Sampling measurement methods, and source characterization.
Environ. Sci. Technol., 28, 555-562 (1994).

Wilson, S.C. and K.C. Jones: Bioremediation of soil contaminated with polycyclic aromatic hydrocarbons (PAHs): A review. Environ. Pollut., 81, 229-249 (1993).

Wu, H., B. Sun and J. Li: Polycyclic aromatic hydrocarbons in sediments/soils of the rapidly urbanized lower reaches of the River Chaohu, China. Int. Jr. Res. Pub. Hlth., 16, 1-16 (2019)

Xu, J., J.Y. Guo, G.R. Liu, G.L. Shi, C.S. Guo, Y. Zhang and Y.C. Feng: Historical trends of concentrations, source contributions and toxicities for PAHs in dated sediment cores from five lakes in western China. Sci. Total Environ., 470, 519-526 (2014).

Yendry, J.P, O.O. Oyedibu, M. P. Guilherme, H. A. Paulo, L. Almeida, E. Sofia, A. Olajumoke and P. Morenikeji: Polycyclic aromatic hydrocarbons in soils and sediments in Southwest Nigeria. Env. Poll., 259, 113732 (2020)

Yunker, M.B., R.W. Macdonald, R. Vingarzan, R.H. Mitchell, D. Goyette and S. Sylvestre: PAHs in the Fraser river basin: A critical appraisal of PAH ratios as indicators of PAH source and composition. Org. Geochem., 33, 489-495 (2002).

Yussof, I. and M. Omar: "Pembangunan Langkawi dan mobiliti pekerjaan penduduk di Lembangan Kilim." ('Langkawi development and employment mobility in the local community in Kilim'). In: Lembangan Kilim: Warisan Budaya dan Sumber Asli Langkawi ('Lembangan Iklim: Culture and Natural Resources Heritage, Langkawi') (Eds.: M.S. Leman, I. Komoo, A. Latiff and H. Salleh). Lestari UKM, Bangi, Malaysia, pp. 53-79 (2005).

Zakaria, M.P., T. Okuda and H. Takada: Polycyclic aromatic hydrocarbon (PAHs) and hopanes in stranded tar-balls on the coasts of peninsular Malaysia: Applications of biomarkers for identifying sources of oil pollution. Mar. Pollut. Bull., 42, 1357-1366 (2001).

Zhao, Q., Y. Li, X. Chai, L. Zhang, L. Xu, J. Huang, P. Ning and S. Tian: Interaction of nano carbon particles and anthracene with pulmonary surfactant: he potential hazards of inhaled nanoparticles. Chemosphere., 215, 746-752 (2019).

Zhu, L., Y. Chen and R. Zhou: Distribution of polycyclic aromatic hydrocarbons in water, sediment and soil in drinking water resource of Zhejiang Province, China. J. Hazard. Mater., 150, 308$316(2008)$ 